\title{
The New Russia? Yes. Comment on Recent Findings from 'Is New Russia New?'
}

\section{ANIKIN*}

\begin{abstract}
*Vasiliy A. Anikin - PhD in Economics, Associate Professor, Faculty of Economic Sciences, Senior Research Fellow, Institute for Social Policy, National Research University Higher School of Economics; Senior Research Fellow, Institute of Sociology, Russian Academy of Sciences. Address: of. 4331, building 4, 26, Shabolovka St., Moscow, 119049, Russian Federation. E-mail: vanikin@hse.ru
\end{abstract}

Citation: Anikin V. (2017) The New Russia? Yes. Comment on Recent Findings From 'Is New RussiaNew?'.MirRossii,vol.26,no4,pp.51-70.DOI:10.17323/1811-038X-2017-26-4-51-70

This paper addresses the general question raised in the recent study 'Is New Russia New?'(2016). The author of this article develops the idea that new Russia is new. He argues with some of the findings of the considered study. The main points are as follows: the changes in Russia are better understood within a transitional discourse; the unique way of Russia is to constitute a Democratic Power integrated within a European civilization; the 'statist'path of Russia is not a curse, but a tunnel of opportunities for social solidarity; the social structure of Russia is mostly based on income stratification and class elements, which are likely to coexist with post-industrial traps, like unskilled labor, or the precariat; the human development of Russia is higher than in the Soviet Union, though its growth has reached saturation point; neoliberal policy is a kind of new rut for Russia, which crucially obstructs the structural reforms and perspectives for its successful transition towards the informational age that has yet to arrive.

Key words: post-transition, new Russia, social structure, human development, neoliberalism

\section{Introduction}

New Russia requires a new understanding. A recently published, co-authored book 'Is New Russia New?' provides fertile ground for a new round of discussions regarding the 'old' questions on Russia [Shkaratan, Yastrebov 2016]. Is new Russia new? What 
has Russia gone through, transitions or transformations? To what extent does path dependency show the development and modernization of Russia? What can we say about the social structure of Russian society, 30 years after perestroika? What are the 'new' and 'old' patterns in the social stratification and inequality of contemporary Russian society? Are there any achievements in the human development of Russia and what is the role of the dominant ideology justifying this?

All these questions are covered in this profound study, shedding light on the main headwinds against Russia in its modernization and future development. In their study, the authors stress the following findings: 1) The recent socio-cultural and economic dynamics of Russia are characterized by transformation, rather than transition; 2) Russia is neither Europe nor Asia but is a unique civilization, comprising features of both; 3) There is a dualism in the social structure in contemporary Russia, revealed in the existence of free market (or pseudo-market) relationships and related forms of inequality existing under umbrella of a 'statist' and an estate-based system of stratification; 4) these confirm the authors' 'path dependency' hypothesis; 5) furthermore, they highlight the specific features of Russian marketization proving Russia has yet to achieve the levels of human development comparable with that of the pre-perestroika period; 6) contemporary Russia is suffering from neoliberalism and the policy of diminishing state welfare principles.

Although these points are of great importance; they have to be discussed broadly. I think that each of these points has both a 'Yes' and 'No' answer to the question about the uniqueness of the 'Russian way', showing the contradiction underlying each of the listed findings. The purpose of this paper is to show that 'New Russia' is new; however, this novelty is supported by both new and old institutions.

\section{Post-transition vs transformation}

The transition-vs-transformation discourse (TTD) emerged after the 1980s, when some states initiated a transition towards a new world requiring new economic, social, and political systems. Cambridge University Press even started a new series of books devoted to the changes 'after 1985'. In most cases, the transition view on the economy was inspired by the successful catch-up of developing countries such as Singapore, Japan, South Korea, China. In Russia, TTD started after perestroika, the period of the early 1990s, when the old command-based economy was disrupted mainly for the sake of a transition to a market economy. In light of this, most researchers (primarily economists) started to call Russia a transition economy.

However, sociologists (and some economists inspired by Polaniyi's views) usually assess the functionality of the transitional view on the processes that happened after the 1980s skeptically, preferring a transformational approach to understand the economic and social changes in society. The most prominent followers of this approach are Stompka, Yadov, and Zaslavskaya. Each endeavored to show that post-communist countries were experiencing fundamental changes, which were hard to forecast and administrate. The Institute of Sociology of the Russian Academy of Science published a series 'Russia Is Transforming', where researchers discussed the changes occurring in post-Soviet

1 See http://www.isras.ru/year-book.html, accessed 25 July 2017. 
Russia. Most of these processes were perceived as traumatic, since they were caused by the diminishing of the Soviet welfare system in a new economy free of social obligations and the planned economic system.

Rapid marketization, which intensified the economic and social inequality in Russia, increased dramatically during 1990s. The level of injustice also increased and it remains high even today [Mareeva, Tikhonova 2016]. The dissolution of the Soviet Union caused a deep crisis for most branches of manufacturing and social services defense and aircraft industries, science informational and computing services, health and social security, public education, culture and art. Engineers, health and teaching professionals, the Soviet middle class, were left abandoned and eventually became 'the new poor'. It was a time when of Russia became less enthusiastic scholars and more skeptical about the future of the 'transition framework' for the analysis of the economic and social changes occurring in Russia.

Although market-influenced economic activities started to grow (e.g. finance and insurance, accommodation and food services, administrative and support services, retail trade, professional and technical activities, etc.), Russia remained a 'crisis society' [Lapin 1994]. The majority of the working population still occupy 'crisis-type' occupations holding middle-skilled jobs in sales, trade, administration, taxi driving and security [Anikin 2012; Anikin (1) 2013]; that is, jobs of 'generic labor' with low requirements for human capital and skills development. The deindustrialization of the 1990-2000s has not led to upskilling. The relative percentage of intellectual professionals decreased from 1993 to 2003 [Shkaratan 2009], which weakened Russia's transition towards a knowledge economy. It was also a contribution to the growing skepticism about the efficiency of the transition-influenced views on Russia.

Perestroika was premised on the idea that marketization and liberalization would become a fruitful ground for further transition towards 'modern capitalism' [Weber [1924] 1978], or 'Marx's account of the development of capitalism' [Clarke 2007] i.e. industrial capitalism - in Russia. However, in its failure to import Western institutions of market economy [Polterovich 2001], Russia displayed a partial transition to a market economy revealed in growing forms of quasi-market structures and a symphonia between state and business. Further, the rapid voucher privatization in Russia in part relied on the Coase Theorem ${ }^{2}$ (Peter Aven's interview ${ }^{3}$ ). However, the outcome of the Coase Theorem has yet to be achieved. In fact, the 'nomenclature class' who were in charge during the Soviet period converted their political power into economic capital by the accumulation of valuable economic assets in the hands of small cliques [Shkaratan 2007]. These facts have enormously discredited the theory of transition.

A new turn in TTD occurred in the 2000s, when the Russian economy recovered and started to grow. However, the desired transition again failed to happen. The new elites of Russia developed a merchant capitalism which relied on the growing prices for oil and gas which became the main items of national trade. Russia marked time while the situation in external markets was improving. As a result, Russia fell prey to the

\footnotetext{
2 The Coase Theorem states that, if there are no transaction costs for trade, private parties can arrive to the efficient solutions to externalities - namely, distribution of property rights - without government intervention regardless of how the property rights are initially allocated [Coase 1960].

3 See https://www.kommersant.ru/doc/211815, accessed 25 July 2017.
} 
'resource curse' and Dutch disease [Algieri 2011]. Again, Russia was thrown back from the transition to a fully fledged knowledge economy.

Very soon these issues were reassessed as 'wrong transformations'; the transition theory was rebranded under the broader term 'modernization'. Successful examples of catch-up development of some countries - Singapore, South Korea, China and Japan - contributed a lot to strengthening the research agenda formulated via modernization discourse. Russia was considered a 'normal country' [Shleifer 2005] that required structural reforms to boost modernization of its socio-cultural institutions. A transition can be considered complete when the necessary qualitative changes (transformations) are manifest. In the course of this discourse, some authors considered the changes happening in Russia a 'protracted' transition; that is, a transition, which is stable in its incompleteness.

Burawoy [2002] differentiates the terms 'transformation' and 'transition'; in his opinion, in no context - social, economic, or political - does Russia demonstrate an 'involutionary transition'; that is, a transition 'without transformation'. In fact, the transition of any system is not possible without transformations. If we manifest a transition, it implies transformation, positive or negative, which exists a priori. Transition may be accompanied by the desired transformations of the system or there may be undesired changes, which should be reassessed and corrected by government intervention. In other words, once Burawoy found evidence for an involutionary transition in Russia, it would be better to speak of wrong transformations, rather than 'transition without transformation'.

In contrast to Burawoy's interpretations of 'involutionary transition', transformations can manifest 'without transition'. Listing the transformations that have failed to occur in Russia, Burawoy stresses the indicators of directed change which could be attributed to pivotal features of a new transition phase. He argues that Russia completed its first transformational phase before 1998, and afterwards switched to transition. However, we know that by 1998 Russia had overcome the main bifurcation point, after which renationalization was hardly possible as the main property rights were held by private parties and the basic elements of market infrastructure were established and brutally maintained to support the flourishing merchant capitalism, free trade and financial capital. These and other arguments made some researchers consider the period of 19901998, which Burawoy considered 'the first transformational phase', a phase of transition to a market economy [Kapas, Czegledi 2007]; an involutionary transition with 'wrong transformations'.

Broadly speaking, Russia has deviated from the qualitative transformations inherent in a competitive system [Davis, Moore 1945] within a late- or post-industrial context [Anikin 2013]. In recent years, the deviation from the competitive system became very salient, and questionable ${ }^{4}$ for two main reasons: 1) the strict budget constraints of the 1990s were softened due to growing economic prosperity and the budget surplus remained at a substantial level until the crisis of 2014-2016;2) Russia started to face the challenges of growing international competition for the information economy [Castells, Kiseleva 2000]. The situation of the late 2000s was therefore completely different from the 1990s. The dramatic effects of the recent economic crisis of 2014-2016 showed that Russia should learn how to develop in prosperous years. This is one the main headwinds of a protracted transition.

\footnotetext{
4 See the results of sociological surveys of the population of Russia indicating the growing expectations of Russians to the government activity in light of growing prosperity of the society [Anikin 2011].
} 
The protracted transition is the double challenge for Russia. On the one hand, Russia needs to complete the transition to an innovation-based economy, which is expected to overcome the resource curse. The roots of this challenge deepened during the 1965 Soviet economic reform ${ }^{5}$ which stalled in the late 1970-1980s when Russia sought to move from industrial to late industrial development [Anikin (2) 2013]. On the other hand, Russia needs to integrate into the world economy as a producer of information technologies to become internationally competitive in the post-industrial world [Castells 2004].

In other words, the challenges of a protracted transition have become one of the key issues in the post-transition period. In light of this, a very important question is how Russia will move against this and other headwinds [Anikin (2) 2017] blowing against the transition towards a post-industrial society. The recent political and economic isolation of Russia, occurring shortly after the Ukrainian crisis in 2013, makes this question highly relevant and important.

\section{The unique Russian way}

In the course of the (post)transition to an informational age, one needs to understand whether a society is ready for such a move. What is the benchmark? Should we move towards the countries which successfully caught up, like China, Singapore, Taiwan, Hong Kong, South Korea and Japan, or towards the Western world, like Germany, Great Britain, the USA? In other words, the very practical dilemma about the direction of the transition - West or East - is very typical for Russia. However, the recent crisis of 2014-2016 shows that we should reassess this dilemma with a deeper understanding that 'the Russian way' is a harmony between individualism and statism. It is a way of 'Democratic Power', which is expected to provide a fair development and corresponding opportunities to meet the fundamental interests of various social groups [Anikin 2016].

As mentioned above, the European experience of forming nation states on the basis of liberal democracy, multiculturalism and market-based individualism are not applicable in Russia. Western institutions are not supported on a cultural level. Moreover, Russians are not likely to identify themselves with Europeans. During the recent crisis 2014-2016, caused by the political and economic isolation of Russia, this negative identity of Russians became even stronger. In 2015 - the worst year of the recent crisis about three quarters of Russians considered Russia 'a unique civilization, that will never absorb the western way of living' ${ }^{6}$.

The absolute majority of citizens of New Russia perceive their country in the sense of 'Power' $(88 \%$ believe that state must favor the interests of the society over the interests of a particular individual), which smoothes out the ideological, political and cultural contradictions, that were cleaving Russian society during the first transitional phase

\footnotetext{
5 The 1965 Soviet economic reform also known the Kosygin reform or Liberman reform was focused on developing the market-influenced stimuli of the economic organisations by decreasing the relative share of production plans appointed from the Centre in line with external directives, rather than internal incentives of the companies linked to the real demand of people and other organisations. According to these reforms, organisations would be granted freedom to choose suppliers and customers. For these purposes they were expected to modernise their chains on the innovations basis.

6 Here and elsewhere, we use survey data from the IS RAS monitoring waves, 2014-2017. Author's calculations (shortly, the IS RAS data), http://www.isras.ru/rezyume_ross_obschestvo_v_usloviyah_krizis_realnosti, accessed 25 July 2017.
} 
[Akhiezer 2001; Zubarevich 2010; Petukhov 2006; Petukhov 2008]. However, statist values do not mean that Russians support totalitarianism and deny human rights. The absolute majority (96\%) of Russians believe that people should have a right to defend their opinion even if others think differently. About $89 \%$ of Russians think that people should have the right to actively defend their views via demonstrations; however, this struggle must not disrupt public order. Individualism is therefore harmonized with societal interests.

These settings can be met only under the democratic arrangements of society. In 2016, 63\% of Russians believed that Russia 'should become a democratic state which protects human rights and freedom for self-expression'. The other $37 \%$ were confident that 'democracy will not take root in Russia'. The socio-cultural system of New Russia supports the democratic principal of 'power for society', and not vice versa [Zdravomyslov 2000, p. 25]. Thus, we see that the power-statist perception of Russia does not imply totalitarianism and Eastern despotism. Further, it contradicts them as it contains a cultural mechanism to balance the absolute power of the state with a principal of universal justice and meeting the interests of all the members of the society.

Though Russians negatively perceive the neoliberal institutions of the western societies, the beliefs of Russians in their civilizational uniqueness implies not only a response to the policy of Western countries, but mainly reflects the fundamental perception of the unique specificity of the development of their country. During the relatively peaceful periods of the relationships between Russia and Western countries (for example, 2006 and 2013), the percentage of those who believed that Russia to be a unique civilization which will never adopt Western ways of living, was still very high about $65 \%$. In 1996 - the period of overall euphoria about the convergence between Russia and the West $-58 \%$ of Russians said that 'Russia should follow the path of the developed countries of the West' [Gudkov 2004].

The self-identification of the population of transitioning Russia, founded mostly in 'contrast with the West rather than with the East', has deep historical roots and going back at least three hundred years [Nureev, Latov 2011, p. 27]. The social perception of Russia as a unique civilization is therefore a stably reproduced socio-cultural phenomenon. This is a distinctive feature of the Russian national identity, which supports the civilization theory and contributes empirically to theoretical papers assuming the existence of 'the Russian civilization' as a reality per se [Leksin 2012], see also [Leksin 2017], [Shkaratan, Yastrebov 2016].

It would be misleading to consider this feature of the Russian national identity an outcome of sociocultural rigidity and traditionalism. The demand for modernization among Russians is very high. According to Levada Centre [Public Opinion-2015 2016, p. 48], the Great Power of Russia is associated with the 'well-being of the people' (64\% in November, 2014 and November 2015) and the high 'economic and industrial potential of the country' (60\% and 58\%, respectively). The perception of Russia in the sense of civilizational uniqueness does not contradict the modernization agenda. Moreover, it constitutes a framework for the expectations of a successful transition in the future [Pliskevich 2016].

The statist values coexist with 'we-identities' that merge Russians with European citizens and, therefore, determine the 'tunnel of opportunities' for socio-cultural integration with the Western world. In 2015, the main values of Russians remain converged with the main socio-cultural settings of the European civilization. According to the IS RAS data, $89 \%$ of Russians associate themselves with 'people of the same profession and occupation category' and a majority of Russians (69\%) identity with the middle class, which is also 
very popular among Western Europeans. $90-92 \%$ of Russians identify themselves with 'people of similar views' and 'people having similar hobbies and activities'. About $84 \%$ claim that they are 'citizens of Russia'. From the socio-cultural perspective Russia is much closer to the countries of Western Europe than previously believed. This does not indicate a socio-cultural cleave (or dualism) in Russia, but the socio-cultural foundation for fruitful coexistence and even integration with Western civilization.

\section{A new agenda for path dependency}

From this perspective, the main issue for the successful transition of New Russia to the informational age relates more to the 'power curse' (or, the crisis of power [Zdravomyslov 2000]), than to any sort of 'civilizational rut' [Ilyin 2017]. The power curse of New Russia is revealed in the separation of supreme power from the people. Frankly, Russians are somewhat reluctant to any signs of the absolutization of power, but very sensitive to any disconnection of power from society. This is not a civilizational rut. The power curse is very common for those political elites who tend to absolutize power and behave aggressively towards their citizens [Scott 2002]. The contemporary Syria might be a clear example of it. Viewed from a historical perspective, the power crisis happened in France in the late 18th century, led to the revolution and ruined the Empire and, primarily the supreme power. The alienation of power from the nation became a crucial historical counterpoint on the eve of the Russian revolution and, therefore, appeared as one of the main factors of the dissolution of the Russian Empire at the end of the 19th century [Tikhomirov 1905]. A similar alienation of supreme power from the nation was very typical for the late Soviet Union [Lapin 1994]. At the end of 1980s, a crisis in the relationships between political elites and society contributed enormously to the crisis of power and the fall of the Soviet Union [Zdravomyslov 1999] and to the greater emancipation of political relationships in the 1990s [Kachanov 1997, p. 5].

Recent studies highlight the growing concerns [Srednij klass 2016] of Russians regarding how the political elites realize the main functions of the state. The corruption and bureaucratization of office-holders and the privatization of the supreme power by a few cliques considerably increase the growing alienation of power and the dissolution of the norms and values that legitimize the central role of state as the backbone of society [Anikin 2016]. The peoples of Russia who support absolute power on behalf of the development of the state, in fact, do not feel that the elites use this power to meet the fundamental interests of the Russian society in the face of the strong headwinds of marketization and capitalism.

The reality of New Russia is revealed in the overwhelming presence of the market and its inevitable consequences for the social stratification of Russian society [Tikhonova 2014]. The authors of 'Is New Russia New?' highlight that Russia obtained new patterns of social stratification, unknown in Russia before perestroika. These patterns relate not only to income stratification [Anikin, Lezhnina, Mareeva, Slobodenyuk, Tikhonova 2016; Tikhonova 2017], which did not exist in Soviet Union to the same extent, but mainly to distributing to the majority of Russian society elements of social structure that are typical for advanced industrial societies, such as middle class [Srednij klass 2016; Tikhonova, Mareeva 2009], working class [Karavay 2016], lower class and even underclass [Tikhonova 2011]). In light of this, statist forms of stratification related to the distribution 
of power assets, are relevant for upper social classes, mainly office holders, and do not reflect the reality of social differentiation of the majority of the Russian population.

Moreover, the authors of 'Is New Russia New? 'contributed to the study of the postindustrial forms of stratification, such as the precariat. It was shown that the precariat is formed of people with a lack of cultural and social capital. There is a growing number of cases when precarious status becomes an outcome of individual choices of those young Russians who value freedom and creative activities. Employment instability and nonstandard work become a tunnel of opportunities for creative workers. However, most of the working population suffer from employment instability (which coincides more with the 'classical' theory of the precariat [Standing 2011]). The majority of workers hold 'bad jobs' that do not require much human capital [Anikin (1) 2017]. The new reality of Russia is a constitution of 'generic labor' [Castells 2000] encompassing up to two thirds of the working population [Anikin (1) 2017]. All these features are new to Russia and some of these features are new even to Western societies.

\section{Over-education and slow rates of growth in human development ${ }^{7}$}

The quality of Russia's transition should be understood and reassessed through the lens of human development. This is one the key arguments of the book and particularly in David Lane's chapter [Lane 2016, pp. 53-75]. Although levels of gross national income recovered by 2010 s in Russia (and other post-socialist countries), the large inequalities eliminated these effects, as the benefits of economic growth were not distributed among the mass population.

The social dimension of economic development - and focus on its 'comprehensive outcomes' - was conceptualized by Amartya Sen [Sen 1983; Sen 1999]. Based on his ideas, the United Nations Development Program (UNDP) has been drawing the attention of both academics and politicians to the issue of a human-oriented economy since 1991 [Stiglitz, Sen, Fitoussi 2010]; at the center of such an economy should be placed the human being rather than abstract financial figures. To capture the achievements of various countries in the field of human development, the UNDP proposed the Human Development Index (HDI).

Table 1 summarizes the HDI estimations for the last 25 years $^{8}$. The average achievements in human development of catch-up countries vary from very high (Singapore, Honk-Kong, South Korea, Japan, and the Baltic states) and high (Brazil, China, Turkey, and Ukraine) to median (South Africa and India) and low (e.g. Nigeria, Afghanistan, Syrian Arab Republic, and the Central African Republic). Among BRICS and CIS, Russia's HDI rank is the highest; 49th place out of 188. In 2015 Russia was at the bottom of the list of the countries of 'very high human development'; although, in 2014 Russia shared its HDI rank with Belarus holding the highest rank among the countries of 'high human development'. In 2015, Brazil and China remained their positions in the human development group of countries of high HDI values (Brazil's rank is 79, China 90). Two other BRICS countries, South Africa (119th) and India (131th), remained in the human development group of 'medium' HDI values.

\footnotetext{
7 The arguments for the following section I also develop in [Anikin (2) 2017].

8 The most recent data available from 2015.
} 
Table 1. Human Development Index, 1990-2015

\begin{tabular}{|c|c|c|c|c|c|c|c|c|c|}
\hline \multicolumn{2}{|c|}{ HDI rank } & \multirow[t]{2}{*}{ Country } & \multicolumn{5}{|c|}{ HDI value } & \multicolumn{2}{|c|}{ Change in HDI rank } \\
\hline 2014 & 2015 & & 1990 & 2000 & 2010 & 2014 & 2015 & 2009-2014 & 2010-2015 \\
\hline \multicolumn{10}{|c|}{ Very High Human Development } \\
\hline 1 & 1 & Norway & 0,849 & 0,917 & 0,939 & 0,948 & 0,949 & 0 & 0 \\
\hline 6 & 4 & Germany & 0,801 & 0,860 & 0,912 & 0,924 & 0,926 & 3 & 0 \\
\hline 11 & 5 & Singapore & 0,718 & 0,820 & 0,911 & 0,924 & 0,925 & 11 & 0 \\
\hline 8 & 10 & United States & 0,860 & 0,884 & 0,910 & 0,918 & 0,920 & -3 & -3 \\
\hline 12 & 12 & Hong Kong & 0,781 & 0,825 & 0,898 & 0,916 & 0,917 & 2 & 3 \\
\hline 14 & 14 & Sweden & 0,815 & 0,877 & 0,901 & 0,909 & 0,913 & -1 & -1 \\
\hline 14 & 16 & United Kingdom & 0,775 & 0,866 & 0,902 & 0,908 & 0,909 & -2 & -4 \\
\hline 20 & 17 & Japan & 0,814 & 0,856 & 0,884 & 0,902 & 0,903 & -3 & 1 \\
\hline 17 & 18 & Korea (Republic of) & 0,731 & 0,820 & 0,884 & 0,899 & 0,901 & 0 & 0 \\
\hline 30 & 30 & Estonia & 0,728 & 0,781 & 0,838 & 0,863 & 0,865 & 3 & 2 \\
\hline 37 & 37 & Lithuania & 0,731 & 0,757 & 0,826 & 0,846 & 0,848 & -1 & -1 \\
\hline 39 & 38 & Saudi Arabia & 0,698 & 0,742 & 0,803 & 0,845 & 0,847 & 10 & 9 \\
\hline 41 & 42 & United Arab Emirates & 0,726 & 0,798 & 0,824 & 0,836 & 0,840 & -6 & -4 \\
\hline 44 & 43 & Hungary & 0,703 & 0,769 & 0,821 & 0,834 & 0,836 & -4 & -4 \\
\hline 46 & 44 & Latvia & 0,703 & 0,728 & 0,810 & 0,828 & 0,830 & -5 & 1 \\
\hline 50 & 49 & Russian Federation & 0,733 & 0,720 & 0,785 & 0,805 & 0,804 & 8 & 5 \\
\hline 48 & 51 & Kuwait & 0,713 & 0,786 & 0,792 & 0,799 & 0,800 & -3 & -1 \\
\hline \multicolumn{10}{|c|}{ High Human Development } \\
\hline 50 & 52 & Belarus & .. & 0,681 & 0,787 & 0,798 & 0,796 & 4 & 1 \\
\hline 59 & 56 & Bulgaria & 0,700 & 0,713 & 0,775 & 0,792 & 0,794 & 0 & 3 \\
\hline 56 & 56 & Kazakhstan & 0,690 & 0,685 & 0,766 & 0,793 & 0,794 & 6 & 7 \\
\hline 66 & 66 & Serbia & 0,714 & 0,709 & 0,757 & 0,775 & 0,776 & -1 & 0 \\
\hline 72 & 71 & Turkey & 0,576 & 0,653 & 0,737 & 0,764 & 0,767 & 16 & 9 \\
\hline 71 & 71 & Venezuela & 0,634 & 0,672 & 0,756 & 0,769 & 0,767 & -4 & -4 \\
\hline 75 & 79 & Brazil & 0,611 & 0,685 & 0,724 & 0,754 & 0,754 & 3 & 7 \\
\hline 81 & 84 & Ukraine & 0,706 & 0,673 & 0,734 & 0,748 & 0,743 & 2 & -1 \\
\hline 90 & 90 & China & 0,499 & 0,592 & 0,700 & 0,734 & 0,738 & 13 & 11 \\
\hline \multicolumn{10}{|c|}{\begin{tabular}{|l|} 
Median Human Development \\
\end{tabular}} \\
\hline 107 & 107 & Moldova & 0,652 & 0,597 & 0,672 & 0,701 & 0,699 & 2 & 0 \\
\hline 116 & 119 & South Africa & 0,621 & 0,629 & 0,638 & 0,665 & 0,666 & 4 & 2 \\
\hline 120 & 120 & Kyrgyzstan & 0,615 & 0,593 & 0,632 & 0,662 & 0,664 & 3 & 3 \\
\hline 130 & 131 & India & 0,428 & 0,494 & 0,580 & 0,615 & 0,624 & 6 & 4 \\
\hline \multicolumn{10}{|c|}{ Low Human Development } \\
\hline 152 & 152 & Nigeria & .. & .. & 0,500 & 0,525 & 0,527 & 2 & -1 \\
\hline 171 & 169 & Afghanistan & 0,295 & 0,340 & 0,454 & 0,479 & 0,479 & 0 & -2 \\
\hline 187 & 188 & Central African Republic & 0,320 & 0,314 & 0,361 & 0,347 & 0,352 & 0 & -1 \\
\hline
\end{tabular}

Source: The UNDP data ${ }^{9}$. Author's compilations.

9 Available at: http://hdr.undp.org/en/composite/trends, accessed 24 February 2017 and 25 July 2017. 
In 2014 Russia passed some European countries such as Serbia (66th HDI rank) and Bulgaria (56th); in 2015 it surpassed Romania (50th), mainly because it downgraded the HDI rank. In 2014 Russia was nearing Kuwait (48th), a Persian Gulf country that traditionally invests a lot in the nation's human capital ${ }^{10}$. From 1990 to 2014/2015, Russia showed the best increase in HDI rank among industrially advanced societies; however, the rates of growth in human development in Russia were lower than in Singapore, Saudi Arabia, Turkey, China, and Kazakhstan (2015). Taking into account the issue of over-education [Anikin (2) 2017] and the drop in real wages caused by the current economic turmoil in Russia, we document a slowdown of the rates of growth in human development, which might remain in the nearest future.

Russia did not use all the opportunities offered by its recent economic growth. Economic development in Russia was not oriented towards increasing the opportunities and economic prosperity of the mass population. Ultimately, the resource curse of Russia became more salient and inertial. This shows that the market alone is not an optimal mechanism for achieving the desired results in human development, or at least for reproducing the social welfare of state socialism [Lane 2016]. The cases of successful transitions of post-socialist countries (like Poland or Belorussia) reveal the exclusive role of the state. However, the Russian state failed to meet the goal of a balanced transition and escaped from its social obligations - with both trends getting worse over time.

\section{Neoliberalism, exploitation, and social alienation ${ }^{11}$}

'Is New Russia New?' devotes a whole chapter to the issues of risk society, critically developed by social pessimists like Beck [Beck 2009] and Bauman [Bauman 2009]. This chapter revives the issues of the neoliberalism of post-modernity reflected through three domains: 1) different forms of exclusion, particularly, the financial exclusion of a majority of the population from the main facilities and public goods; 2) the switch to non-standard employment [Kallenberg, Reskin, Hudson 2000]; and 3) state escapism from welfare responsibilities under the growing commodification of relationships and marketization.

The essence of neoliberalism is revealed in the transitioning of economic and social risks from organizations and institutions to individuals. The neoliberal regime is considered perhaps the most powerful headwind against Russia's transition to a postindustrial society. The Russian state is gradually decoupling from the social sphere. The monetization of social support and benefits, cutting unemployment benefits, resentment toward the decrease of living standards and increasing inequality, independent regulation of the labor market and high exploitation are just a few examples of the neoliberal course gradually being established in Russia.

\footnotetext{
10 In the Persian Gulf states, education is strongly associated with religion. This can affect the HDI ranks of the given countries, which should be taken into account in international comparisons. However, a contribution of religious education to HDI should not be exaggerated, as HDI includes also data on national income and health. These states reroute their rental incomes to social prosperity and development. According to the latest World Health Organization (WHO) data published in 2016, the average life expectancy at birth in Russia is 70,5 (107 ${ }^{\text {th }}$ rank), which is remarkably lower than in Kuwait ( 74,7 years, $73^{\text {th }}$ rank) or Saudi Arabia ( 74,5 years, $77^{\text {th }}$ rank).

11 I have also published the main arguments for the following section in [Anikin (2) 2017].
} 
Russia is currently cutting spending on spheres strategically important to developing the intellectual economy and advanced human potential of the population. According to Table 2, Russia has a very limited budget for education. During the period of economic growth, federal spending on education as a proportional of total expenditure was more than 5\%. However, during the period of economic crisis, it decreased to 3,91\% in 2015. Notwithstanding the over-education trend in Russia, these figures are extremely low compared with those for industrially advanced economies like Germany, Great Britain, Norway, or the US. According to the Federal Treasury data, the educational expenditures of Russia includes pre-school spending, the relative share of which is extremely low, around $0,2 \%$ in 2015 . However, these particular investments in pre-school development programs should be of a primary interest to industrially developed states [Heckman 2000].

Table 2. Federal spending structure in 2011-2015, \% of the total expenditures

\begin{tabular}{|l|c|c|c|c|c|}
\hline & $\mathbf{2 0 1 1}$ & $\mathbf{2 0 1 2}$ & $\mathbf{2 0 1 3}$ & $\mathbf{2 0 1 4}$ & $\mathbf{2 0 1 5}$ \\
\hline National Issues & $\mathbf{7 , 1 2}$ & $\mathbf{6 , 2 9}$ & $\mathbf{6 , 3 7}$ & $\mathbf{6 , 3 1}$ & $\mathbf{7 , 1 6}$ \\
\hline National Defence & 13,88 & 14,05 & 15,77 & 16,71 & 20,36 \\
\hline National Security and Law enforcement & 11,53 & 14,29 & 15,45 & 14,07 & 12,58 \\
\hline National Economy & 16,38 & 15,28 & 13,86 & 20,65 & 14,87 \\
\hline Housing and Utilities & 2,56 & 1,77 & 1,33 & 0,81 & 0,92 \\
\hline Environmental protection and ecology & 0,16 & 0,17 & 0,18 & 0,31 & 0,32 \\
\hline Education & 5,06 & 4,68 & 5,04 & 4,30 & 3,91 \\
\hline Culture and Cinematography & 0,77 & 0,70 & 0,71 & 0,66 & 0,58 \\
\hline Health Care & 4,57 & 4,76 & 3,76 & 3,61 & 3,30 \\
\hline Social Policy & 28,63 & 29,93 & 28,73 & 23,29 & 27,31 \\
\hline Physical culture and Sport & 0,40 & 0,35 & 0,51 & 0,48 & 0,47 \\
\hline Mass Media & 0,57 & 0,60 & 0,58 & 0,50 & 0,53 \\
\hline Public Debt Service & 2,40 & 2,48 & 2,70 & 2,80 & 3,32 \\
\hline Inter-budget Transfers & 5,97 & 4,65 & 5,01 & 5,50 & 4,37 \\
\hline
\end{tabular}

Source: The Federal Treasure of Russia data ${ }^{12}$.

The expenditure on the health care system is the smallest among industrially developed countries. Despite additional transfers from the Health Insurance Fund, the spending on health care continued to decrease; it was 3,3\% of total federal expenditure in 2015. Given that Russia has not yet performed the so-called epidemiological revolution [De Flora, Quaglia, Bennicelli, Vercelli 2005], this figure unambiguously indicates

12 Available at: http://datamarts.roskazna.ru/razdely/rashody/rashody-po-razdelam-podrazdelam/rashody-po-razdelam-i-podrazdelam/?paramPeriod=2015, accessed 25 July 2017. 
the lack of institutional investment in human beings and, consequently, explains lower rates of life expectancy and higher mortality rates from preindustrial diseases even in big cities. The Russian government has also suspended deductions for contributions to pensions and reduced the economic security of working people, as they are forced now to secure their old age using private funds. The total spending on social policy decreased from $29,93 \%$ in 2012 to $23,29 \%$ in 2014 . Although, Russia slightly increased relative spending on pensions in 2015, its level is still below 2011.

The public discourse supported by the government remains neoliberal. In drafting the most recent budget, the Finance Ministry made efforts 'to optimize cost structures' (i.e. to cut budgets) by proposing not paying the base part of the retirement pensions to working pensioners. Strong public resistance meant the government refused to support this and other initiatives of the Finance Ministry.

Another remarkable indicator of state escapism is the high level of socioeconomic insecurity of Russian employees and its positive elasticity to economic shocks (Table 3). In 2104 only $56 \%$ of the working population said that their legal labor rights were followed. Between 2014 and 2015 there was a sharp decrease in this number to $47 \%$ in 2015 (i.e. a 16\% relative change). Although the situation in this sphere slightly improved in 2016 - primarily regarding the key positions such as the prompt payment of salary and official employment - in 2017, the year of the post-crisis negative stabilization, their values had just returned to their starting points, if that.

Table 3. The socio-economic security of Russians at their workplaces, 2014-2017

\begin{tabular}{|l|c|c|c|c|}
\hline Indicators & $\mathbf{2 0 1 4}$ & $\mathbf{2 0 1 5}$ & $\mathbf{2 0 1 6}$ & $\mathbf{2 0 1 7}$ \\
\hline The prompt payment of a salary & 92 & 89 & 91 & 84 \\
\hline Officially employed & 76 & 70 & 75 & 75 \\
\hline "White" salary & 66 & 63 & 62 & 66 \\
\hline Paid holidays and sick leave & 68 & 60 & 59 & 62 \\
\hline All these labor rights are abided & 56 & 47 & 49 & 48 \\
\hline Additional social benefits are provided & 15 & 6 & 5 & 9 \\
\hline
\end{tabular}

Source: The IS RAS monitoring waves, 2014-2017. Author's calculations.

Note: Figures represent the percentages of the working population.

In most cases, legal labor rights are more likely to be abused in generic labor. The labor rights of professionals and managers were less affected during the crisis; however, their social benefits, provided before 2013, were reduced. According to Table 3, the relative share of those received additional benefits shrank three times, from $15 \%$ in 2014 to $5 \%$ in 2016; although in 2017 they were partially recovered. Since the major recipients of these benefits are managers and skilled professionals, this may lead to the risk of demotivation and the alienation of the most qualified categories of the Russian working force.

Russia is not the only country facing risks of neoliberalism. There is a convergence of non-liberal states against neoliberalism. Most cases of successful catch-up development ('Asian Tigers') demonstrate alternative, directed market coordination, which could be 
taken into account by the ruling class in Russia. However, the specific path of New Russia deals with institutional policies that seem to intentionally ignore this kind of experience.

\section{Conclusion}

Is New Russia new? In most respects, yes. Russia has never faced the challenge of a (post)transition to an information age; it has never experienced harmony between individualism and statist values; Russia has never faced the challenges of over-education and deskilling; Russian society has never had classes and such deep income stratification; and Russia has never lost so much because of neoliberal policies.

We cannot ignore the range of crucial transformations which Russia has experienced during the 30 years since perestroika. Some of these aspects (for example, the class system) are likely to become new institutional ruts for Russia. Different social groups are likely to stick to their specific paths (such as the exploitation for generic labor and continuing education for the middle class). Moreover, the neoliberal economic policy that leave people face to face with free market forces is likely to be a path that Russian elites, supposedly, will never give up.

Some of the 'civilizational ruts' need not be considered in dysfunctional terms. For example, I tend to believe that the 'neostatist' mode of the socio-cultural system plays a positive role in crises, supporting social coherence. The statist values of Russians can help to mobilize the resources of the population to promote modernization, that is, a successful transition towards the fully fledged knowledge economy. However, this socio-cultural model has the higher risks of the 'power curse', which has happened to Russia several times.

The Book 'Is New Russia New? ' gives fertile ground for the further research into what is new wine and what are old skins. It concludes that Russia has accumulated a critical level of fundamental prerequisites for a 'great' civilizational shift which might happen under the pressure of the powerful civilizational diffusion that has taken place in Russia during the last 30 years.

\section{References}

Algieri B. (2011) The Dutch Disease: Evidences From Russia. Economic Change and Restructuring, vol. 44, no 3, pp. 243-277.

Akhiezer A.S. (2001) Arkhaizatsiya v rossijskom obshchestve kak metodologicheskaya problema [Archaization of the Russian Society as a Methodological Dilemma]. Obshchestvennye nauki i sovremennost', no 2, pp. 89-100.

Anikin V.A. (2011) Work in the Lives of Russians. Sociological Research, vol. 50, no 6, pp. 3-16.

Anikin V.A. (2012) The Modernization Potential of the Professional Structure of the Employed Population of Russia. Sociological Research, vol. 51, no 6, pp. 44-80. DOI:10.2753/SOR1061-0154510605.

Anikin V.A. (1) (2013) Mode of Socio-economic Development and Occupational Structure: The Case of Contemporary Russia. Transition Studies Review, vol. 19, no 4, pp. 397-415. DOI:10.1007/s11300-013-0256-8.

Anikin V.A. (2) (2013) Motivation to Work in Russia: The Case of Protracted Transition from Noncompetitive to Competitive System. The Journal of Comparative Economic Studies, no 8, pp. 35-60. 
Anikin V.A. (2016) Krizis i natsional'noe samosoznanie rossiyan [Crisis and Russian National Identity]. Monitoring obshchestvennogo mneniya: ehkonomicheskie i sotsial'nye peremeny, no 5, pp. 203-232.

Anikin V.A. (1) (2017) Occupational Propensity for Training in a Late Industrial Society: Evidence from Russia. International Journal of Training and Development, vol. 21, no 4, in print.

Anikin V.A. (2) (2017) Russia in Post-transition: New Frontiers. The Journal of Comparative Economic Studies, no. 12, pp. 5-19.

Anikin V.A., Lezhnina Y.P., Mareeva S.V., Slobodenyuk E.D., Tikhonova N.N. (2016) Income Stratification: Key Approaches and Their Application to Russia. Working paper BRP 02/PSP/2016, Moscow: HSE. Available at: https://www.hse.ru/mirror/pubs/lib/data/ access/ram/ticket/32/15004561235148fe 7695654ea2fd18cf2d6b2d73b0/02PSP2016.pdf, accessed 31 August2017.

Bauman Z. (2009) The The Absence of Society. Contemporary Social Evils (ed. Utting D.), Bristol: The Policy Press, pp. 147-157.

Beck U. (2009) World at Risk, Cambridge: Polity.

Burawoy M. (2002) Transition Without Transformation: Russia's Involutionary Road to Capitalism. Locating Capitalism in Time and Space: Global Restructurings, Politics and Identity (ed. Nugent D.), Stanford, California: Stanford University Press, pp. 290-310.

Castells M. (2000) Materials for an Exploratory Theory of the Network Society. British Journal of Sociology, vol. 51, no 1, pp. 5-24.

Castells M. (2004) Informationalism, Networks, and the Network Society: A Theoretical Blueprint. The Network Society. A Cross-cultural Perspective (ed. Castells M.), Northampton: Edward Elgar, pp. 3-45.

Castells M., Kiseleva E. (2000) Rossiya i setevoe obshchestvo. Analiticheskoe issledovanie [Russia and the Network Society: Analytical Study]. Mir Rossii, no 1, pp. 23-51.

Clarke S. (2007) The Development of Capitalism in Russia, London, New York: Routledge.

Coase R.H. (1960) The Problem of Social Cost. The Journal of Law and Economics, vol. 3, no 1 , pp. 1-44.

Davis K., Moore W.E. (1945) Some Principles of Stratification. American Sociological Review, vol. 10, no 2, pp. 242-249.

De Flora S., Quaglia A., Bennicelli C., Vercelli M. (2005) The Epidemiological Revolution of the 20th century. The FASEB Journal, vol. 19, no 8, pp. 892-897.

Gorshkov M.K., Tikhonova N.E. (eds.) (2016) Srednij klass v sovremennoj Rossii. Opyt mnogoletnikh issledovanij [The Middle Class in Contemporary Russia: Decades of Study], Moscow: Ves' mir.

Gudkov L. (2004) Negativnaya identichnost'. Stat'i 1997-2002 godov [Negative Identity. Collection of papers 1997-2002], Moscow: Novoe literaturnoe obozrenie.

Heckman J.J. (2000) Policies to Foster Human Capital. Research in Economics, vol. 54, no 1, pp. 3-56.

Ilyin V.I. (2017) Struktura istoricheskoj kolei Rossii: problemy metodologii [The Structure of Russia's Historical Path Dependency]. Mir Rossii, no 4, pp. 30-50.

Kachanov Yu.L. (1997) Proizvodstvo politicheskogo polya v sovremennoj Rossii [Establishing of the Political Field in Contemporary Russia]. Sotsiologicheskie issledovaniya, no 11, pp. 3-12.

Kallenberg A.L., Reskin B.F., Hudson K. (2000) Bad Jobs in America: Standard and Nonstandard Employment Relations and Job Quality in the United States. American Sociological Review, vol. 65 , no 2, pp. $256-278$.

Kapas J., Czegledi P. (2007) What Does Transition Mean?: Post-socialist and Western European Countries Paralleled. The Journal of Comparative Economic Studies, no 3, pp. 3-28.

Karavay A. (2016) Chelovecheskij kapital rossijskikh rabochikh: Sostoyanie i faktory [The Human Capital of the Russian Working Class: Status and Factors]. Vestnik Instituta Sotsiologii, no 17, pp. 91-112.

Lane D. (2016) Skhodyashchiyesya sotsial'no-ekonomicheskiye posledstviya transformatsiy postsotsialisticheskikh stran [Converging Social and Economic Consequences of Transformation of Post-socialist Countries]. Nova li novaya Rossiya [Is New Russia New?] (eds. Shkaratan O., Yastrebov G.), Moscow: Universitetskaya kniga, pp. 53-75.

Lapin N.I. (1994) Krizisnyj sotsium. Nashe obshchestvo v trekh izmereniyakh [Society in Crisis. Considering Our Society in Three Dimensions], Moscow: IP RAS. 
Leksin V.N. (2012) Russkaya tsivilizatsiya: Opyt sistemnoj diagnostiki [The Russian Civilization: a Case for System Diagnostics]. Mir Rossii, no 4, pp. 3-39.

Mareeva S.V., Tikhonova N.E. (2016) Bednost' i sotsial'nye neravenstva v Rossii v obshchestvennom soznanii [Public Perceptions of Poverty and Social Inequality in Russia]. Mir Rossii, no 2, pp. 37-67.

Nureev R., Latov Yu. (2011) Kogda i pochemu razoshlis' puti Rossii i Zapadnoj Evropy (podkhod s pozitsii institutsional'noj ekonomicheskoj istorii) [When and Why Have the Paths of Russia and Western Europe Diverged? A View from Institutional Economic Theory]. Mir Rossii, no 4, pp. 24-59.

Obshchestvennoe mnenie-2015 [Public opinion-2015] (2016). Levada-Tsentr. Available at: http:/www.levada.ru/sbornik-obshhestvennoe-mnenie/obshhestvennoe-mnenie-2015/, accessed 31 August 2017.

Petukhov V.V. (2006) Dinamika politicheskikh predpochtenij i politicheskogo uchastiya gorodskogo srednego klassa [Dynamics of Political Preferences and Political Activity of the Middle Class]. Gorodskoj srednij klass v sovremennoj Rossii: Analiticheskij doklad [Urban Middle Class in Contemporary Russia: Analytical Report] (eds. Gorshkov M.K., Tikhonova N.E.), Moscow: IS RAS, pp. 127-142.

Petukhov V.V. (2008) Dinamika mirovozzrencheskikh i ideologicheskikh ustanovok rossiyan [Forthcoming elections and social dynamics]. Monitoring obshchestvennogo mneniya: ehkonomicheskie $i$ sotsial'nye peremeny, no 1, pp. 48-61.

Pliskevich N.M. (2016) "Path dependence" i problemy modernizatsii mobilizatsionnogo tipa ['Path Dependence' and the Problem of Modernization from Above]. Mir Rossii, no 2, pp. 123-143.

Polterovich V.M. (2001) Transplantatsiya ekonomicheskikh institutov [Transplantation of Economic Institutions]. Ekonomicheskaya nauka sovremennoj Rossii, no 3, pp. 24-50.

Scott J. (2002) Social Class and Stratification in Late Modernity. Acta Sociologica, vol. 45, no 1, pp. 23-35.

Sen A. (1983) Development: Which Way Now? The Economic Journal, vol. 93, no 372, pp. 745-762.

Sen A. (1999) Development as Freedom, Oxford: Oxford University Press.

Shkaratan O. (2007) The Russian Transformation: A New Form of Etacratism? The Transformation of State Socialism: System Change, Capitalism, or Something Else? (ed. Lane D.), New York: Palgrave Macmillan UK, pp. 143-158.

Shkaratan O.I. (2009) Sotsial'no-ekonomicheskoe neravenstvo $i$ ego vosproizvodstvo $v$ sovremennoj Rossii [Socio-economic Inequality and Its Reproduction in Contemporary Russia], Moscow: OLMA Media Grupp.

Shkaratan O.I., Yastrebov G.A. (eds.) (2016) Nova li novaya Rossiya? [Is New Russia New?], Moscow: Universitetskaya kniga.

Shleifer A. (2005) A Normal Country: Russia After Communism, Cambridge, London: Harvard University Press.

Standing G. (2011) The Precariat: The New Dangerous Class, London: A\&C Black.

Stiglitz J.E., Sen A., Fitoussi J.-P. (2010) Mismeasuring Our Lives: Why GDP Doesn't Add Up, NewYork: The New Press.

Tikhomirov L.A. (1905) Monarkhicheskaya gosudarstvennost'. Ch. 1-4. Chast'tret'ya. Russkaya gosudarstvennost'[Monarchic Statehood: Books 1-4. Book Three. The Russian Statehood], Moscow: Universitetskaya tipografiya na Strastnom bul'vare.

Tikhonova N.E. (2011) Nizshij klass v sotsial'noj strukture rossijskogo obshchestva [The Lower Class in the Social Structure of Russia]. Sotsiologicheskie issledovaniya, no 5, pp. 24-35.

Tikhonova N.E. (2014) Sotsial'naya struktura Rossii: teorii i real'nost' [Social Structure in Russia: Theory and Reality], Moscow: Novyj Khronograf.

Tikhonova N.E. (2017) Stratifikatsiya po dokhodam v Rossii na fone drugikh stran [Income Stratification in Russia in Comparison with Other Countries]. Obshchestvennye nauki $i$ sovremennost' (in printing).

Tikhonova N.E., Mareeva S.V. (2009) Srednij klass: Teoriya i real'nost' [The Middle Class: Theroy and Reality], Moscow: Al'fa-M.

Weber M. ([1924] 1978) Economy and Society (eds. Roth G. , Wittich C.), Berkeley: University of California Press. 
Zdravomyslov A.G. (1999) Raspad SSSR kak rezul'tat krizisa vlasti [Collapse of the USSR as a Result of the Crisis of Power]. Zdravomyslov A.G. Sotsiologiya rossijskogo krizisa [Sociology of the Russian Crisis], Moscow: Nauka.

Zdravomyslov A.G. (2000) Vlast' i obshchestvo v Rossii: Krizis 90-kh godov [Power and Society in Russia: the Crisis of the 1990s]. Obshchestvennye nauki $i$ sovremennost', no 6, pp. 25-34.

Zubarevich N.V. (2010) Goroda kak tsentry modernizatsii ekonomiki i chelovecheskogo kapitala [Cities as Centres for the Modernization of the Economy and Human Capital]. Obshchestvennye nauki i sovremennost', no 5, pp. 5-19.

\title{
Новое вино в старые мехи: размышления по мотивам книги «Нова ли новая Россия?»
}

\author{
В.А. АНИКИН*
}

\begin{abstract}
*Василий Александрович Аникин - кандидат экономических наук, доцент, факультет экономических наук, старший научный сотрудник, Институт социальной политики, Национальный исследовательский университет «Высшая школа экономики»; старший научный сотрудник, Институт социологии РАН. Адрес: 119049, Москва, ул. Шаболовка, д. 26, стр. 4, офис 4331. E-mail: vanikin@hse.ru
\end{abstract}

Цитирование: Anikin V. (2017) The New Russia? Yes: Comment on Recent Findings From 'Is New Russia New?'. Mir Rossii, vol. 26, no 4, pp. 51-70. DOI: $10.17323 / 1811-038 X-2017-26-4-51-70$

Настоящая статья затрагивает ключевые вопросы коллективной монографии «Нова ли новая Россия?» [Шкаратан, Ястребов 2016]. Автор статьи признает уникальность и своевременность такой постановки вопроса и склоняется к позитивному ответу на него. Прошло 30 лет после начала перестройки. Куда пришла Россия? Удалось ли России достичь поставленных целей изменений или их вовсе не существовало? Логика статьи выстраивается вокруг обсуждения ключевых выводов коллег, которые, по мнению автора статьи, можно изложить в виде шести тезисов:

1) недавняя социокультурная и экономическая динамика России характеризуется, скорее, трансформационными процессами, и транзитивный взгляд на них менее состоятелен;

2) Россия не является Европой, равно как и не является Азией, однако объединяет черты и того, и другого, представляя собой уникальную цивилизацию, и, следовательно, должна изучаться исходя из этого посыла;

3) в современной России сложился дуализм социальной структуры, который проявляет себя в одновременном существовании рыночных (или псевдорыночных) отношений и основанных на них неравенств наряду с этакратическими и сословно-слоевыми формами социальной стратификации;

4) все это обязывает авторов рассматриваемой монографии поддержать гипотезу о «колее», по которой катится Россия, находящаяся в зависимости от исторического пути развития; 
5) обратная сторона медали заключается в том, что Россия развивает агрессивные формы рыночных отношений, следствием чего становится неудовлетворительным уровень человеческого развития, который едва достиг доперестроечных показателей;

6) как следствие, современная Россия испытывает негативные последствия агрессивных рыночных реформ и глобальных рисков неолиберализма и социального отчуждения, которые на них наслаиваются.

В полемике с этими тезисами автор статьи развивает следующие аргументы:

1. Понимание сегодняшних изменений в современной России невозможно без оценки будущих перспектив экономического и социального развития, которые так или иначе связаны с вызовами постиндустриального развития. Современная Россия стоит перед задачей перехода 2.0, которая предполагает постановку новой цели для большинства переходных обществ, - не просто достичь фазы постиндустриального развития (завершив в случае России «буксующий» переход предыдущей стадии), но и эффективно интегрироваться в информационную экономику посредством капитализации передовых технологических разработок, интеллектуальной собственности и уникальных компетенций. Эта задача требует разработки теории перехода 2.0 и более тщательного изучения опыта азиатских стран, осуществивших успешный переход к новой социально-экономической реальности.

2. Подобные задачи возвращают нас к вопросам о том, кто мы есть и насколько уникальны процессы, происходящие в России. Второй тезис данной работы состоит в том, что уникальный путь России - в построении демократической державы, интегрированной в европейский цивилизационный пояс. Основываясь на кризисных эмпирических оценках, автор статьи приходит к мысли о том, что этакратическая модель ценностно-нормативной системы, ренессанс которой наблюдается в последние годы в России, способствует установлению солидарности в обществе и обеспечению его гармоничного развития в условиях экономических шоков и внешнеполитической турбулентности. При этом державный характер национальной идентичности россиян не только не имеет ничего общего с принципами тоталитаризма и азиатского деспотизма, но даже противоречит им, основываясь на ценностях индивидуализма, равенства всех перед законом и вселенской справедливости. Таким образом, «цивилизационная колея» этакратии, скорее, является не проклятием России, а ее коридором возможностей для осуществления солидарности в обществе и мобилизации творческих ресурсов микросоциума с целью решения глобальных задач.

3. Несмотря на то, что на словах россияне отрицают все европейское, в вопросе макроидентичности они ассоциируют свои ценности с ценностями, близкими к европейским, - «люди своей профессии», которые «имеют схожие увлечения и взгляды на жизнь». Это является базисом ценностно-нормативной интеграции России и Европы, к которой наша страна оказывается ближе, чем к «великим» азиатским народам. Многое в этом направлении будет зависеть от действий национальной элиты, которая пока только изучает опыт технологической модернизации Азии.

4. Социальная структура России имеет глубокую доходную дифференциацию, которой не было в советские годы. Помимо прочего, данные многолетних исследований, в том числе выполненных в период финансово-экономического кризиса 2014-2016 гг, показывают, что в современной России уже в целом 
сложился средний класс, наблюдаются очертания низшего класса и андеркласса. Элементы этакратической системы стратификации наблюдаются лишь по отношению к тем редким слоям населения, которые имеют доступ к дефицитному властному капиталу, не затрагивая массовые слои населения. Отечественная социология по-прежнему испытывает дефицит исследований по проблематике рабочего класса. Отчасти этот пробел решен в рассматриваемой монографии в главе, посвященной проблеме прекариата в современной России, ключевым фактором которой являются ограничения в накоплении социального и культурного капиталов. Прекаризация труда и его включение в зону родовой рабочей силы становятся новой ловушкой («колеей») перехода 2.0, сопровождающего страны на пути постиндустриального развития.

5. Авторы выявили, что формальные уровни образования уже не являются тем фактором, который способен решить проблему прекаризации. Несмотря на выводы авторов монографии, последние данные говорят о том, что Россия достигла более высоких показателей человеческого развития, чем в советское время. Однако цена этого достижения - избыточность высшего образования и его неизбежная девальвация. Более того, качество человеческого развития остается по-прежнему на низком уровне, прежде всего в связи с замедлением темпов роста доходов и крайне низкими показателями (для индустриально развитых стран) в области здравоохранения. Россия по-прежнему не преодолела эпидемиологический переход, что сказывается на высоких показателях смертности от внешних причин и инфекционных заболеваний.

6. Главным риском (и «колеей») новой России является кризисный характер властных отношений, проявляемый в отказе в отчуждении власти от народа. Кризис власти представляет собой наибольшую опасность именно в обществах с этакратической моделью национального самосознания. Отчуждение верховной власти от народа в условиях, когда общество делегирует этой власти полномочия по осуществлению модернизации и легитимирует примат макросоциальных интересов над индивидуальными, может порождать дестабилизацию и раскол социетального целого. В России отчуждение власти от народа на протяжении 30 лет последовательно принимает форму неолиберальной политики, которая лишает население защиты от «невидимой руки рынка» и тем самым блокирует структурные реформы и перспективы России на успешный переход к постиндустриальному этапу развития.

Ключевые слова: переход 2.0, новая Россия, социальная структура, человеческое развитие, неолиберализм

\section{Литература}

Аникин В.А. (2016) Кризис и национальное самосознание россиян // Мониторинг общественного мнения: экономические и социальные перемены. № 5. С. 203-232.

Ахиезер А.С. (2001) Архаизация в российском обществе как методологическая проблема // Общественные науки и современность. № 2. С. 89-100.

Горшков М.К., Тихонова Н.Е. (ред.) (2016) Средний класс в современной России. Опыт многолетних исследований. М.: Весь мир. 
Гудков Л. (2004) Негативная идентичность. М: Новое литературное обозрение.

Здравомыслов А.Г. (1999) Распад СССР как результат кризиса власти // Здравомыслов А.Г. Социология российского кризиса. М.: «Наука».

Здравомыслов А.Г. (2000) Власть и общество в России: Кризис 90-х годов // Общественные науки и современность. № 6. С. 25-34.

Зубаревич Н.В. (2010) Города как центры модернизации экономики и человеческого капитала // Общественные науки и современность. № 5. С. 5-19.

Ильин В.И. (2017) Структура исторической колеи России: проблемы методологии // Мир России. № 4. С. 30-50.

Каравай А.В. (2016) Человеческий капитал российских рабочих: Состояние и факторы // Вестник Института Социологии. № 17. С. 91-112.

Кастельс М., Киселева Э. (2000) Россия и сетевое общество. Аналитическое исследование // Мир России. № 1. С. 23-51.

Качанов Ю.Л. (1997) Производство политического поля в современной России // Социологические исследования. № 11. С. 3-12.

Лапин Н.И. (1994) Кризисный социум. Наше общество в трех измерениях. М.: Институт философии РАН.

Лексин В.Н. (2012) Русская цивилизация: Опыт системной диагностики // Мир России. № 4. С. 3-39.

Лэйн Д. (2016) Сходящиеся социально-политические последствия трансформаций постсоциалистических стран // Шкаратан О.И., Ястребов Г.А. (ред.) Нова ли новая Россия? М.: Университетская книга. С. 53-75.

Мареева С.В, Тихонова Н.Е. (2016) Бедность и социальные неравенства в России в общественном сознании // Мир России. № 2. С. 37-67.

Нуреев Р.М., Латов Ю.В. (2011) Когда и почему разошлись пути России и Западной Европы (подход с позиции институциональной экономической истории) // Мир России. № 4. С. 24-59.

Общественное мнение-2015 (2016) // Левада-Центр // http://www.levada.ru/sbornik-obshhestvennoemnenie/obshhestvennoe-mnenie-2015/

Петухов В.В. (2006) Динамика политических предпочтений и политического участия городского среднего класса // Горшков М.К., Тихонова Н.Е. (ред.) Городской средний класс в современной россии: Аналитический доклад. М.: Институт социологии РАН. С. 127-142.

Петухов В.В. (2008) Динамика мировоззренческих и идеологических установок россиян // Мониторинг общественного мнения: экономические и социальные перемены. № 1 . C. $48-61$.

Плискевич H.M. (2016) "Path dependence” и проблемы модернизации мобилизационного типа // Мир России. № 2. С. 123-143.

Полтерович В.M. (2001) Трансплантация экономических институтов // Экономическая наука в современной России. № 3. С. 24-50.

Тихомиров Л.А. (1905) Монархическая государственность. Ч. 1-4. Часть третья. Русская государственность. М.: Университетская типография на Страстном бульваре.

Тихонова Н.Е. (2011) Низший класс в социальной структуре российского общества // Социологические исследования. № 5. С. 24-35.

Тихонова Н.Е. (2014) Социальная структура России: теории и реальность. М.: Новый Хронограф.

Тихонова Н.Е. (2017) Стратификация по доходам в России на фоне других стран // Общественные науки и современность (в печати).

Тихонова Н.Е., Мареева С.В. (2009) Средний класс: Теория и реальность. М.: Альфа-М.

Шкаратан О.И. (2009) Социально-экономическое неравенство и его воспроизводство в современной России. М.: ОЛМА Медиа Групп.

Шкаратан О.И., Ястребов Г.А. (ред.) (2016) Нова ли новая Россия? М.: Университетская книга. Algieri B. (2011) The Dutch Disease: Evidences From Russia // Economic Change and Restructuring, vol. 44, no 3, pp. 243-277.

Anikin V.A. (2011) Work in the Lives of Russians // Sociological Research, vol. 50, no 6, pp. 3-16. Anikin V.A. (2012) The Modernization Potential of the Professional Structure of the Employed Population of Russia // Sociological Research, vol. 51, no 6, pp. 44-80. DOI:10.2753/ SOR1061-0154510605. 
Anikin V.A. (1) (2013) Mode of Socio-economic Development and Occupational Structure: The Case of Contemporary Russia // Transition Studies Review, vol. 19, no 4, pp. 397-415. DOI:10.1007/s11300-013-0256-8.

Anikin V.A. (2) (2013) Motivation to Work in Russia: The Case of Protracted Transition from Noncompetitive to Competitive System // The Journal of Comparative Economic Studies, no 8, pp. 35-60.

Anikin V.A. (1) (2017) Occupational Propensity for Training in a Late Industrial Society: Evidence from Russia // International Journal of Training and Development, vol. 21, no 4, in print.

Anikin V.A. (2) (2017) Russia in Post-transition: New Frontiers // The Journal of Comparative Economic Studies, no 12, pp. 5-19.

Anikin V.A., Lezhnina Y.P., Mareeva S.V., Slobodenyuk E.D., Tikhonova N.N. (2016) Income Stratification: Key Approaches and Their Application to Russia. Working paper BRP 02/PSP/2016, Moscow: HSE. Available at: https://www.hse.ru/mirror/pubs/lib/data/ access/ram/ticket/32/15004561235148fe7695654ea2fd18cf2d6b2d73b0/02PSP2016.pdf, accessed 31 August 2017.

Bauman Z. (2009) The Absence of Society // Contemporary Social Evils (ed. Utting D.), Bristol: The Policy Press, pp. 147-157.

Beck U. (2009) World at Risk, Cambridge: Polity.

Burawoy M. (2002) Transition Without Transformation: Russia's Involutionary Road to Capitalism // Locating Capitalism in Time and Space: Global Restructurings, Politics and Identity (ed. Nugent D.), Stanford, California: Stanford University Press, pp. 290-310.

Castells M. (2000) Materials for an Exploratory Theory of the Network Society // British Journal of Sociology, vol. 51, no 1, pp. 5-24.

Castells M. (2004) Informationalism, Networks, and the Network Society: A Theoretical Blueprint // The Network Society. A Cross-cultural Perspective (ed. Castells M.), Northampton: Edward Elgar, pp. 3-45.

Clarke S. (2007) The Development of Capitalism in Russia, London, New York: Routledge.

Coase R.H. (1960) The Problem of Social Cost // The Journal of Law and Economics, vol. 3, no 1 , pp. $1-44$.

Davis K., Moore W.E. (1945) Some Principles of Stratification // American Sociological Review, vol. 10, no 2, pp. 242-249.

De Flora S., Quaglia A., Bennicelli C., Vercelli M. (2005) The Epidemiological Revolution of the 20th century // The FASEB Journal, vol. 19, no 8, pp. 892-897.

Heckman J.J. (2000) Policies to Foster Human Capital // Research in Economics, vol. 54, no 1, pp. 3-56.

Kallenberg A.L., Reskin B.F., Hudson K. (2000) Bad Jobs in America: Standard and Nonstandard Employment Relations and Job Quality in the United States // American Sociological Review, vol. 65, no 2, pp. 256-278.

Kapas J., Czegledi P. (2007) What Does Transition Mean?: Post-socialist and Western European Countries Paralleled // The Journal of Comparative Economic Studies, no 3, pp. 3-28.

Scott J. (2002) Social Class and Stratification in Late Modernity // Acta Sociologica, vol. 45, no 1 , pp. 23-35.

Sen A. (1983) Development: Which Way Now? // The Economic Journal, vol. 93, no 372, pp. 745-762.

Sen A. (1999) Development as Freedom, Oxford: Oxford University Press.

Shkaratan O. (2007) The Russian Transformation: A New Form of Etacratism? // The Transformation of State Socialism: System Change, Capitalism, or Something Else? (ed. Lane D.), New York: Palgrave Macmillan UK, pp. 143-158.

Shleifer A. (2005) A Normal Country: Russia After Communism, Cambridge, London: Harvard University Press.

Standing G. (2011) The Precariat: The New Dangerous Class, London: A\&C Black.

Stiglitz J.E., Sen A., Fitoussi J.-P. (2010) Mismeasuring Our Lives: Why GDP Doesn't Add Up, NewYork: The New Press.

Weber M. ([1924] 1978) Economy and Society (eds. Roth G. , Wittich C.), Berkeley: University of California Press. 